\title{
Glutathione-dependent responses of plants to drought: a review
}

\author{
Mateusz Labudda ${ }^{1 *}$, Fardous Mohammad Safiul Azam² \\ 1 Department of Biochemistry, Warsaw University of Life Sciences - SGGW, Nowoursynowska 159, 02-776 Warsaw, Poland \\ 2 Department of Biotechnology and Genetic Engineering, University of Development Alternative, 80 Satmasjid Road, Dhanmondi R/A, Dhaka-1209, Bangladesh
}

\begin{abstract}
Water is a renewable resource. However, with the human population growth, economic development and improved living standards, the world's supply of fresh water is steadily decreasing and consequently water resources for agricultural production are limited and diminishing. Water deficiency is a significant problem in agriculture and increasing efforts are currently being made to understand plant tolerance mechanisms and to develop new tools (especially molecular) that could underpin plant breeding and cultivation. However, the biochemical and molecular mechanisms of plant water deficit tolerance are not fully understood, and the data available is incomplete. Here, we review the significance of glutathione and its related enzymes in plant responses to drought. Firstly, the roles of reduced glutathione and reduced/ oxidized glutathione ratio, are discussed, followed by an extensive discussion of glutathione related enzymes, which play an important role in plant responses to drought. Special attention is given to the S-glutathionylation of proteins, which is involved in cell metabolism regulation and redox signaling in photosynthetic organisms subjected to abiotic stress. The review concludes with a brief overview of future perspectives for the involvement of glutathione and related enzymes in drought stress responses.
\end{abstract}

Keywords: abiotic stress; glutathione peroxidase; glutathione reductase; glutathione S-transferase; GSH; reactive oxygen species; S-glutathionylation; water deficit

\section{Introduction}

Drought is considered to be one of the major components of abiotic stress. Water deficit inhibits photosynthesis, induces changes in chlorophyll content and composition, and damages the photosynthetic apparatus [1]. Moreover, dehydration of tissue causes a reduction in the activity of Calvin-Benson-Bassham cycle enzymes and inhibits photochemical activities [2].

It is well established that chloroplast, mitochondria and peroxisomes are a major source of reactive oxygen species (ROS) such as superoxide radicals $\left(\mathrm{O}^{--}{ }_{2}\right)$, hydroxyl radicals $(\mathrm{OH} \cdot)$, singlet oxygen $\left({ }^{1} \mathrm{O}_{2}\right)$, hydrogen peroxide $\left(\mathrm{H}_{2} \mathrm{O}_{2}\right)$ and peroxide radicals $\left(\mathrm{O}_{2}{ }^{\cdot 2-}\right)$. ROS play a dual role in plant biochemistry and physiology. They are important secondary signaling molecules, but equally, they are toxic products of aerobic metabolism that accumulate within cells during oxidative stress [3].

The equilibrium between the generation and the enzymatic and non-enzymatic elimination of ROS may be disturbed by drought. During water deficit, these disturbances in equilibrium result in a sudden increase in cellular redox

\footnotetext{
* Corresponding author. Email: mateusz_labudda@sggw.pl
}

Handling Editor: Grażyna Kłobus potential, which can damage many cell components, including lipids, proteins, and nucleic acids $[4,5]$.

The polyunsaturated fatty acid (PUFA) components of membrane phospholipids are especially susceptible to ROS activity. When ROS levels exceed the capacity of the plant to scavenge, lipid peroxidation (LP) in biological membranes increases. This is supported by data collected over a number of years for a range of plant species under water deficit conditions (Tab. 1). The final products of oxidative modification of lipids are responsible for cell membrane damage including changes to the intrinsic properties of the membrane, such as fluidity, ion transport, loss of enzyme activity and protein cross-linking. These changes eventually result in cell death [6].

The ascorbate-glutathione (AsA-GSH) pathway, also known as the Foyer-Halliwell-Asada cycle, is a central antioxidant defense system for the efficient scavenging of ROS and is thus important for the maintenance of redox homeostasis in plants tissues under stress conditions. Indeed, the AsA-GSH pathway is a key element in the network of biochemical reactions involving antioxidant enzymes and low molecular weight antioxidants with redox properties for the efficient elimination of ROS, and thereby prevents the ROS-mediated oxidative damage of plant tissues $[7,8]$.

Of the low molecular weight antioxidants, tripeptide glutathione (GSH, $\gamma$-L-Glutamyl-L-cysteinylglycine) is 
Tab. 1 The lipid peroxidation processes induced by water deficit in various plants.

\begin{tabular}{ll} 
Species & Reference No. \\
\hline Oats (Avena spp. L.) & {$[56]$} \\
Jutes (Corchorus spp. L.) & {$[57]$} \\
Apple trees (Malus spp. Mill.) & {$[58]$} \\
Maize (Zea mays L.) & {$[59-62]$} \\
Soya bean [Glycine max (L.) Merr.] & {$[5]$} \\
Rapeseed (Brassica napus L.) & {$[29]$} \\
Upland cotton (Gossypium hirsutum L.) & {$[63]$} \\
Wheat (Triticum aestivum L.) & {$[44,64,65]$} \\
Common bean (Phaseolus vulgaris L.) & {$[66]$} \\
Sesame (Sesamum indicum L.) & {$[67]$} \\
Chickpea (Cicer arietinum L.) & {$[68]$} \\
Ramie [Boehmeria nivea (L.) Gaudich.] & {$[69]$} \\
White poplar (Populus alba L.) & {$[70]$} \\
Black locust (Robinia pseudoacacia L.) & {$[70]$} \\
Japanese pagoda tree [Styphnolobium japonicum (L.) & {$[70]$} \\
Schott] & \\
Bee bee tree [Tetradium daniellii (Benn.) T.G. & {$[70]$} \\
Hartley] & \\
Lime (Tilia sp. L.) & {$[70]$} \\
Black ash (Fraxinus sp. L.) & {$[70]$} \\
Pistachio (Pistacia vera L.) & {$[71]$} \\
Cowpea [Vigna unguiculata (L.) Walp.] & {$[72]$} \\
Moroccan alfalfa (Medicago sativa L.) & {$[73]$} \\
Spikemoss [Selaginella lepidophylla (Hook. \& Grev.) & {$[74]$} \\
Spring] & \\
Moss [Dicranella palustris (Dickson) E.F. Warburg] & {$[75]$} \\
Bermudagrass [Cynodon dactylon (L.) Pers.] & {$[76]$} \\
Strawberry (Fragaria orientalis Losinsk.) & {$[77]$} \\
Moss [Tortula ruralis (Hedw.) Gaertn.] & {$[30]$} \\
\hline
\end{tabular}

considered the most important defense thiol in the prevention of oxidative damage in plants. GSH acts as a disulphide reductant and protects protein thiol $(-\mathrm{SH})$ groups, regenerates ascorbate and acts as the substrate for important GSH-metabolism enzymes such as glutathione peroxidases (GPXs, EC 1.11.1.9) and glutathione S-transferases (GSTs, EC 2.5.1.18; Tab. 2).
Plants maintain a high cellular ratio of GSH to its oxidized form GSSG (about 20:1 in unstressed conditions), but GSH reacts with oxidants during environmental stress and becomes converted into GSSG. The intracellular homoeostasis between GSH and GSSG ensures the signaling of a stress response and modulates plant tolerance to abiotic stress. Glutathione reductase (GR, EC 1.6.4.2) catalyzes the NADPH-dependent conversion of GSSG to its GSH form (Tab. 2). This reaction provides the molecules of GSH necessary for active protein function under non-stress and stress conditions [9-11].

Consequently, GPXs, GSTs and GR, in association with superoxide dismutases (SODs), catalase (CAT) and peroxidases, provide an effective way of defending plants against the potential effects of oxidative stress [12]. The components of cellular "glutathione machinery" for the control of plant responses to different abiotic stresses, including drought, are summarized in Fig. 1.

The following review describes recent studies of changes in total reduced GSH, glutathione redox state, the key GSHrelated enzymes and their significance in plant responses to water deficit.

\section{Glutathione in the drought response of plants}

\section{GSH and GSH/GSSG ratio}

GSH or GSH homologues are present in all plant species, where the C-terminal glycine is replaced by other amino acid, for example, glutamate, $\beta$-alanine or serine. GSH is produced in two steps. Firstly, $\gamma$-glutamyl-cysteine is synthesised in an ATP-dependent reaction catalyzed by glutamate-cysteine ligase ( $\gamma$-GCL, EC 6.3.2.2). Then, glutathione synthetase (GSS, EC 6.3.2.3) catalyzes the addition of glycine to $\gamma$-glutamyl-cysteine [13]. Biosynthesis of GSH takes place in the chloroplasts, mitochondria and cytosol [14], and both enzymatic proteins are encoded by single genes with alternate transcription start points related to their subcellular localization [15]. Results collected over a number of years confirm that glutathione related parameters change in various plant species subjected to water deficit conditions (Tab. 3).

Tab. 2 Summary of the glutathione-dependent enzymes, reactions catalyzed, function and their tissue localization.

\begin{tabular}{lll}
\hline Enzyme & Reactions catalyzed & Function \\
\hline Glutathione peroxidase (GPXs) & $\mathrm{H}_{2} \mathrm{O}_{2}+2 \mathrm{GSH} \rightarrow 2 \mathrm{H}_{2} \mathrm{O}+\mathrm{GSSG}$ & $\begin{array}{l}\text { Detoxifies } \mathrm{H}_{2} \mathrm{O}_{2} \text { and lipid hydroperoxides with } \\
\text { GSH as reductor. }\end{array}$ \\
Glutathione S-transferase (GSTs) & $\mathrm{RX}+\mathrm{GSH} \rightarrow \mathrm{HX}+\mathrm{R}-\mathrm{S}-\mathrm{S}-\mathrm{GSH} \mathrm{H}^{\mathrm{y}}$ & $\begin{array}{l}\text { Detoxifies lipid hydroperoxides and exhibit DHAR } \\
\text { activity. Acts as non-catalythic cariers that facilitate } \\
\text { the distribution and transport of various molecules. } \\
\text { Degluthathionylation. }\end{array}$ \\
Glutathione reductase (GR) & GSSG $+\mathrm{NAD}(\mathrm{P}) \mathrm{H} \rightarrow 2 \mathrm{GSH}+$ & Reduces GSSG with NADPH as the reductor. \\
& $\mathrm{NAD}(\mathrm{P})^{+}$ & \\
\hline
\end{tabular}

${ }^{\mathrm{y}} \mathrm{R}$ may be an aromatic, heterocyclic or aliphatic group; X may be a halide, nitrite or sulphate group. ${ }^{\mathrm{z}}$ Gechev et al. [78] and Anjum et al. [25] are used as references for localization of enzymes. apo - apoplast; ch - chloroplasts; cyt - cytosol; DHAR - dehydroascorbate reductase; er - endoplasmic reticulum; mit - mitochondria; nuc - nucleus; per - peroxisomes. 


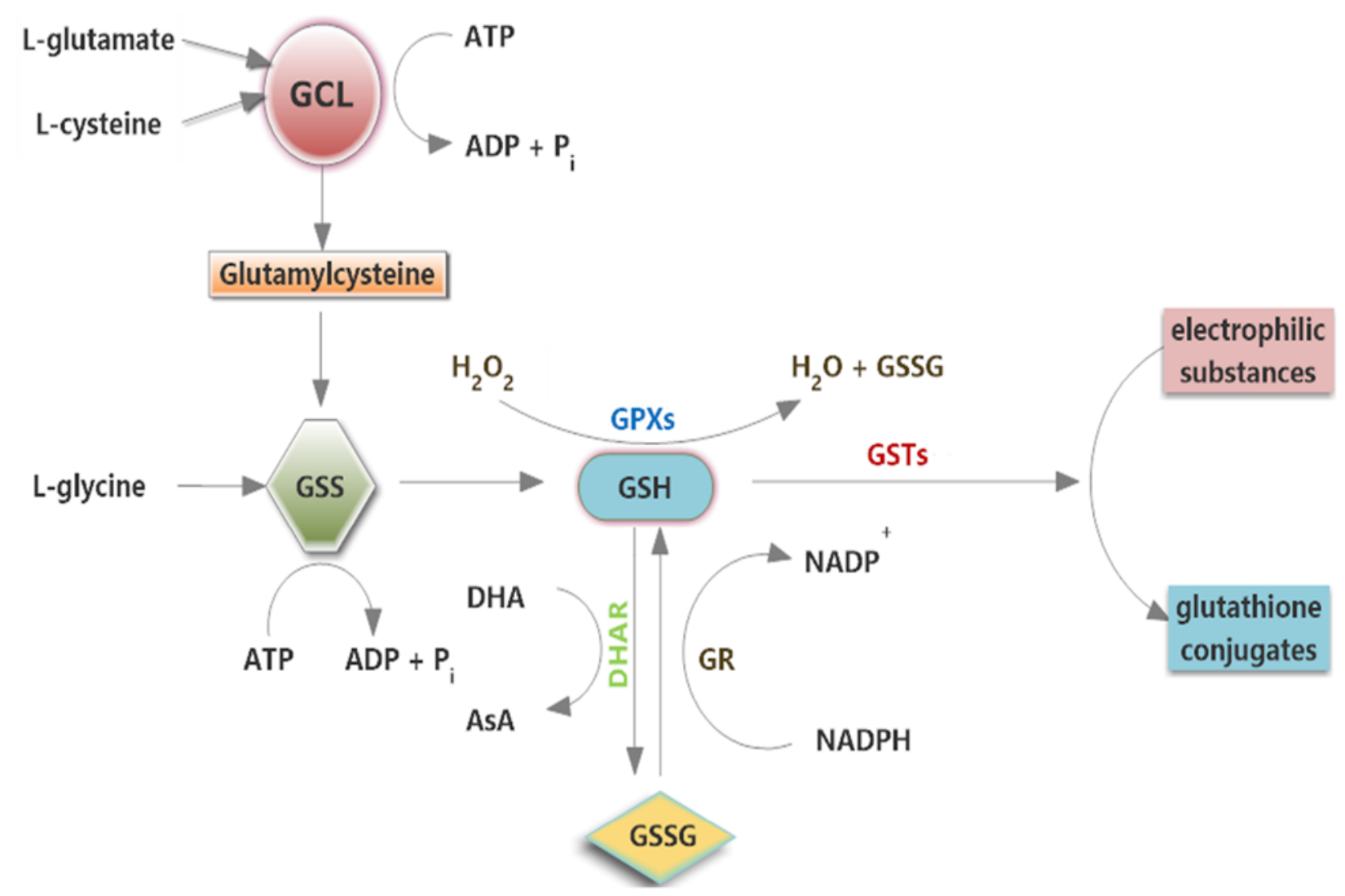

Fig. 1 The cellular "glutathione machinery" in plant responses to abiotic stress.

Sengupta et al. [16] demonstrated a decline in $\gamma$-glutamylcysteine synthetase activity and its transcript levels in the roots of mung bean [Vigna radiata (L.) Wilczek] during long-term water deficit. This is incompatible with the hypothesis that abiotic stress tolerance is associated with an increase in $\gamma$-glutamyl-cysteine synthetase level and activity, together with increases in GSH and Cys concentrations, as demonstrated for salt stress [17]. It should be noted that loss of function of $\gamma$-glutamyl-cysteine synthetase proved lethal during early developmental stages, and GSH deficiency resulted in increased sensitivity to cadmium in Arabidopsis thaliana [18].

Homoglutathione (hGSH), which is characteristic of members of the family Fabaceae, is a homologue of GSH in which the $\mathrm{C}$-terminal glycine is replaced by $\beta$-alanine and it has the same functions as GSH [13]. This compound is an important regulator of nodulation, nitrogen fixation and symbiotic interactions, has antioxidant potential and is involved in the transport of reduced sulphur [11,19]. Researchers have reported increased hGSH synthetase (hGSS) mRNA levels in the leaves of a drought-tolerant cultivar (EPACE-1) of cowpea [Vigna unguiculata (L.) Walp.] during drought stress and desiccation [20]. By contrast, however, water deficit was shown to have no significant effect on the concentrations of GSH and hGSH in the nodules of alfalfa (Medicago sativa L.) [21].

Experimental studies indicate that GSH concentration increases in response to water deficit in sunflower (Helianthus annuus L. cv. Licia Stella) [22]. Furthermore, Herbinger et al. [23] showed that the concentration of GSH increased in flag leaf tissues of drought-sensitive wheat (Triticum aestivum Desf. cv. Nandu) and drought-resistant durum wheat (Triticum durum L. cv. Extradur) cultivars grown in open-top chambers using a water regime equivalent to $40 \%$ soil water capacity.

Pyngrope et al. [24] reported a consistent decline in GSH in a drought-sensitive cultivar (Malviya-36) of indica rice (Oryza sativa L.) in response to an increase in the intensity and duration of water deficiency. However, such changes in GSH level were not detected in the roots of a drought-tolerant cultivar (Brown Gora) subjected to water deficit, even though a statistically significant reduction in GSH levels was observed when its shoots were subjected to an osmotic potential of $-2.1 \mathrm{MPa}$ for $72 \mathrm{~h}$. Conversely, drought-sensitive seedlings treated with $30 \%$ (v/v) polyethylene glycol (PEG-6000) in order to achieve an osmotic potential of $-2.1 \mathrm{MPa}$ for $72 \mathrm{~h}$ showed a $41 \%$ reduction in root GSH and a $61 \%$ reduction in shoot GSH, whereas similarly stressed tolerant plants showed a $22 \%$ reduction in shoot GSH concentration compared with the controls.

Many reports indicate that the GSH/GSSG ratio is an effective marker of cellular redox homeostasis and may be involved in ROS activity perception by plants. In this way, GSH/GSSG may have a direct or indirect key role in regulating and signaling at the transcriptional and/or posttranslational level due to the interaction of these molecules with other cellular redox systems such as glutaredoxin, thioredoxin, peroxiredoxin and, mitogen-activated protein kinases (MAP kinases) [25]. 
Tab. 3 Summary of modulation of glutathione and its dependent enzymes in plant responses to water deficit.

\begin{tabular}{|c|c|c|c|}
\hline Parameter & Species & Response & Reference No. \\
\hline \multirow[t]{7}{*}{ GSH pool } & Helianthus annuus & + & [22] \\
\hline & Triticum durum and Triticum aestivum & + & {$[23]$} \\
\hline & Oryza sativa & $-1 \times$ & [24] \\
\hline & Medicago sativa & $\times$ & [21] \\
\hline & Brassica campestris & + & {$[27]$} \\
\hline & Brassica juncea & + & {$[28]$} \\
\hline & Brassica napus & - & [29] \\
\hline hGSH pool & Medicago sativa & $x$ & [21] \\
\hline \multirow{3}{*}{ GSSG pool } & Brassica campestris & + & [27] \\
\hline & Brassica juncea & + & {$[28]$} \\
\hline & Tortula ruralis & + & [30] \\
\hline total glutathione pool & Brassica napus & - & [29] \\
\hline \multirow[t]{3}{*}{ GSH/GSSG ratio } & Pinus canariensis & - & [26] \\
\hline & Brassica campestris & - & [27] \\
\hline & Brassica napus & + & [29] \\
\hline GCL (activity and mRNA level) & Vigna radiata & - & [16] \\
\hline hGSS mRNA level & Vigna unguiculata & + & [20] \\
\hline \multirow[t]{4}{*}{ GPXs activity } & Helianthus annuus & + & [31] \\
\hline & Glycine max & + & [79] \\
\hline & Beta vulgaris & + & [33] \\
\hline & Cicer arietinum & + & [68] \\
\hline GSTs activity & Zea mays & + & {$[36]$} \\
\hline GSTs (activity and mRNA level) & Triticum aestivum & + & {$[37]$} \\
\hline \multirow[t]{8}{*}{ GR activity } & Gossypium hirsutum and Gossypium barbadense & + & [41] \\
\hline & Anoda cristata & + & [41] \\
\hline & Populus przewalskii & + & [42] \\
\hline & Robusta coffee & $+/-$ & [43] \\
\hline & Brassica napus & + & [29] \\
\hline & Lycopersicon esculentum & + & [45] \\
\hline & Pisum sativum & - & [47] \\
\hline & Triticum aestivum & + & [46] \\
\hline
\end{tabular}

“-”, “+” and “ $x ”$ signs indicate decrease, increase, or unaltered/unaffected, respectively (see main text for more details).

Tausz el al. [26] demonstrated a slight reduction in the GSH/GSSG ratio of the needles of a species of pine tree (Pinus canariensis Chr. Sm. ex DC) exposed to short-term, moderate drought. The authors concluded that the glutathione redox cycling and the equilibrium between GSH and GSSG are sensitive elements of the antioxidative response in pine tree needles and suggested that they possibly have a role in longer-term adaptation processes.

Hossain et al. [27] showed that the concentration of GSSG increased in mustard (Brassica campestris L.) seedlings treated with $20 \%(\mathrm{v} / \mathrm{v})$ polyethylene glycol (PEG-6000) in order to achieve drought stress. The authors speculated that the formation of GSSG under drought stress might be due to the reaction of GSH with oxyradicals generated by oxidative stress, antioxidative enzyme activity that decomposes $\mathrm{H}_{2} \mathrm{O}_{2}$ and organic hydroperoxide or an insufficient increase in glutathione reductase activity.

Furthermore, in seedlings of a second species of mustard (Brassica juncea L. cv. BARI Sharisha 11) subjected to shortterm drought stress conditions, GSH levels increased by $32 \%$ and $25 \%$ with $10 \%(\mathrm{v} / \mathrm{v})$ and $20 \%(\mathrm{v} / \mathrm{v})$ PEG, respectively. Conversely, the concentration of GSSG increased significantly in response to increased levels of water deficit and it was demonstrated that, compared with control plants, the GSSG pools were $48 \%$ and $101 \%$ greater at $10 \%(\mathrm{v} / \mathrm{v})$ and $20 \%$ (v/v) PEG, respectively [28].

Liu et al. [29] assessed the effect of 5-aminolevulinic acid (ALA) on the growth of oilseed rape (Brassica napus L. cv. ZS758) seedlings under water deficit $(-0.3 \mathrm{MPa})$ conditions induced by PEG-6000 treatment and demonstrated that dehydration of the tissues significantly reduced GSH and total glutathione levels, while simultaneously increasing the GSH/GSSG ratio. The compound 5-aminolevulinic acid is an important precursor of tetrapyrrols, such as porphyrins for the synthesis of chlorophylls and heme groups. Recently, it has been suggested that a low concentration of exogenous ALA has a beneficial effect on abiotic stress tolerance/ resistance, regulates plant growth and increases the yields of crops. In the afore-mentioned publication, treatment with $0.1-10 \mathrm{mg} \mathrm{l}^{-1} \mathrm{ALA}$ remarkably improved GSH levels, 
the total glutathione pool and, in particular, the GSH/GSSG ratio, which increased by at least $70 \%$ in relation to control oilseed rape seedlings under water deficit conditions.

Other studies demonstrated that GSSG levels increased in gametophytes of the drought-tolerant moss Tortula ruralis (Hedw.) Gaertn. subjected to water deficit. Moreover, it was observed that GSSG content was correlated negatively with protein synthesis and positively with lipid peroxidation. The author claims that the GSSG level is a good biochemical indicator of oxidative stress induced by drought and suggests that the oxidized glutathione mediates, at least in part, the water deficiency-induced inhibition of protein synthesis [30].

\section{Glutathione peroxidases}

Glutathione peroxidases (GPXs, EC 1.11.1.9) are a diverse group of isozymes having generous substrate spectrum and serve as antioxidant enzymes. They occur in plant cells in the cytosol, chloroplasts, mitochondria, and the endoplasmic reticulum, and catalyze the detoxification of $\mathrm{H}_{2} \mathrm{O}_{2}$ and lipid hydroperoxides with GSH as reductor, and thus protect biomolecules from oxidative damage (Fig. 1, Tab. 2, Tab. 3). It is now known that plant glutathione peroxidases exhibit substrate specificity and can use both GSH and thioredoxins (Trxs) as reductants. However, Trxs are more efficient reducing factors, and thus, the enzymes can functionally be considered to be peroxiredoxins rather than GPXs [25].

Pourtaghi et al. [31] demonstrated that water deficit significantly increased the activity of GPXs in sunflower plants compared with fully-irrigated control plants. Moreover, the relationship between seed yield and GPXs activity in fully irrigated (0.78) and moderately water stressed (0.91) plants was both positive and significant. The authors proposed that GPXs can be used as a marker of drought tolerance in selecting tolerant genotypes under moderate and extreme water deficiency conditions.

Cultivars of soybean (Glycine max L.) seedlings subjected to water deficit stress exhibited a significant increase in GPXs activity [31]. Similarly, Masoumi et al. [32] reported a positive and significant correlation between GPX activity and seed yield under optimal irrigation (0.99) conditions, mild water deficit stress (0.74) and, high water deficit stress (0.95).

Other research suggests that drought increases enzymatic GPXs activity in leaves of sugar beet (Beta vulgaris L.) genotypes. Thus, sugar beet plants might both tolerate and be protected from oxidative damage such as lipid peroxidation by increasing GPXs activity [33].

It has also been found that the over-expression of GPXs enhances plant tolerance to drought. In transgenic Arabidopsis seedlings, over-expressing Synechocystis PCC 6803 GPX-2 in the chloroplasts (ApGPX2) and cytosol (AcGPX2) showed that lipid peroxidation levels were elevated in both the transgenic and wild-type plants, however, the lipid hydroperoxide content in transgenic plants was significantly lower than that in the wild-type. On the basis of the results described in this work, it is clear that the lines of transgenic plants (ApGPX2 and AcGPX2) expressing S. PCC 6803 GPX-2 had enhanced tolerance to oxidative stress caused by drought [34].

Miao et al. [35] isolated two T-DNA insertion mutants of Arabidopsis thaliana glutathione peroxidase3 (ATGPX3) and reported that the $A T G P X 3$ has a dual role in plant biochemistry, the first being the general control of $\mathrm{H}_{2} \mathrm{O}_{2}$ equilibrium, and the second specifically linking abscisic acid ( $\mathrm{ABA}$ ) and $\mathrm{H}_{2} \mathrm{O}_{2}$ signaling during stomatal closure and thus regulating water transpiration. The authors emphasized that the deficiency and over-expression of ATGPX3 reduced and enhanced drought stress tolerance, respectively.

\section{Glutathione S-transferases}

Glutathione S-transferases (GSTs, EC 2.5.1.18) are important phase II, GSH-dependent ROS-scavenging enzymes found in the plant apoplast, cytosol, chloroplasts, mitochondria, and nucleus. This group of enzymes catalyzes the conjugation of GSH to electrophilic sites on a wide range of phytotoxic substrates (Fig. 1, Tab. 2). Currently, very few reports are available on the involvement of GSTs in response to drought (Tab. 3).

Kojić et al. [36] showed that the activity of GSTs increased in the roots of maize (Zea mays L.) at $20 \%$ soil (sand) humidity (drought conditions). In this study, GST activity was detected only in roots. More specifically, GSTs activity of the control group [70\% soil (sand) humidity] increased from 255.5 to $711.6 \mathrm{U} / \mathrm{mg}$ protein under drought stress conditions. The authors claimed that the significant increase in GSTs activity under drought conditions agrees with the induction of oxidative stress in plant tissues evoked by drought.

Gallé el al. [37] analyzed GSTs activity and expression patterns in flag leaves of wheat genotypes differing in their tolerance to dehydration during the grain-filling period. GSTs activity and expression were measured for Triticum aestivum cv. MV Emese, cv. Plainsman (drought tolerant), cv. GK Élet and, cv. Cappelle Desprez (drought sensitive). TaGSTU1B and TaGSTF6 sequences for Triticum aestivum mRNA glutathione transferases, investigated by real-time PCR, showed high-expression levels induced by drought in all of the four analyzed cultivars, but extremely high transcript contents were detected in drought tolerant cv. Plainsman. These data also indicate that expression levels and early induction of two senescence-associated GSTs under drought conditions are correlated with high yield stability. Further, induction of GSTs activity following water deficit was detected earlier in tolerant cultivars than in sensitive ones.

More recently, Chen et al. [38] reported the role of Arabidopsis thaliana glutathione S-transferases U17 (AtGSTU17) in adaptive responses to drought stress by functioning as a negative component of stress-mediated signal transduction pathways. They showed that, when AtGSTU17 was mutated, plants were more tolerant to drought than wild-type Arabidopsis ecotype Columbian plants. Moreover, two knockout T-DNA insertion mutants atgstu17-1 and atgstu17-2 accumulated higher levels of GSH and ABA and exhibited hyposensitivity to ABA during seed germination, smaller stomatal apertures, a lower transpiration rate, better development of primary and lateral root systems, and longer period of vegetative growth compared with wild-type Arabidopsis.

Some experimental studies suggest that the over-expression of GSTs increases drought tolerance in plants. A chloroplastic GST from Prosopis juliflora [39] and a class of the GST gene, GsGST from Glycine soja [40], improved drought stress tolerance in transgenic tobacco. 


\section{Glutathione reductase}

Of the many components of the plant antioxidant system, glutathione reductase (EC 1.6.4.2) is the last enzyme of the ascorbate/glutathione cycle and plays a principal role in the protection of cells from damage induced by oxidative stress. In drought conditions, GR favors maintenance of the GSH pool, thereby intensifying the antioxidative response of the plant (Fig. 1, Tab. 2, Tab. 3).

Ratnayaka et al. [41] examined the effect of mild drought on glutathione reductase activity in two species of cotton (Gossypium hirsutum L. cv. Delta Pine 5415, and Gossypium barbadense L. cv. Pima S-7), together with spurred anoda (Anoda cristata L. Schlecht.). In this study, GR activity was greater in drought-stressed plants of all three species during recovery, but not during drought. Therefore, the authors proposed that elevated GR activity in drought-stressed plants during recovery strongly indicates that drought may result in acclimation to greater water deficit and/or cross-tolerance to other stresses later.

In poplar (Populus przewalskii Maximowicz) cuttings grown under three different watering regimes (100, 50, and $25 \%$ of the field capacity), GR activity significantly increased under progressive drought. Moreover, two contrasting populations of $P$. przewalskii were used in this study. They were originally obtained from wet and dry climate regions and it was demonstrated that the plants from the dry climate population presented greater GR activity than those from the wet climate population grown under the same watering regime. The researchers concluded that the combination of drought avoidance and tolerance mechanisms (including induction of GR activity) conferred on the poplar a high degree of plasticity in response to drought [42].

That induction of GR activity in response to oxidative stress triggered by drought is greater in drought sensitive than in drought tolerant individuals is noteworthy and there is some evidence of intensification of oxidative damage to tissues of sensitive plants. Pinheiro et al. [43], working on clones of robusta coffee (Coffea canephora Pierre ex Froehner) representing both drought tolerant and drought sensitive genotypes subjected to gradual water deficit until the water potential of their leaves was approximately -3.0 $\mathrm{MPa}$, showed that GR activity either increased significantly (67\%, drought sensitive clone) or became reduced (48\%, drought tolerant clone) in drought-stressed plants compared with well irrigated control plants.

As mentioned above, treatment with $0.1-10 \mathrm{mg} \mathrm{l}^{-1}$ ALA remarkably improved GSH, the total glutathione pool and, in particular, the GSH/GSSG ratio in oilseed rape seedlings under water deficit stress. Similarly, GR expression and activity were significantly greater following treatment with $1 \mathrm{mg} \mathrm{l}^{-1}$ ALA during drought. It is probable that greater GR activity triggered by ALA in plants resulted in a large pool of GSH capable of increasing the efficiency of the AsAGSH cycle [29]. Furthermore, Singh et al. [44] observed a strong and positive correlation between GR activity and ascorbate content in wheat roots (0.90) and leaves (0.87) under water deficit.

Recently, the role of the phytohormone ABA in the induction of antioxidant enzymes has been the subject of advanced research. It is worth stating that young and mature leaves of tomato seedlings (Lycopersicon esculentum Mill.) cv. Ailsa Craig (AC) and an ABA-deficient mutant (notabilis) exhibited differences in GR activity. However, the activity of GR remained unchanged following ABA treatment of young and mature leaves of $\mathrm{AC}$, but enzyme activity declined in ABA-treated young leaves of notabilis. Furthermore, the exogenous ABA treatment increased GR activity in young leaves of notabilis under drought, compared with the control plants and those exposed to drought. On the basis of these studies, it can be concluded that enzymatic antioxidants (including GR) synthesized by plants are regulated not only by stress and ABA but also by the developmental stage of individual plants [45].

Another plant hormone, salicylic acid (SA) is a phenolic compound that is able to modulate plant responses to abiotic stresses. Greater drought tolerance was observed in Triticum aestivum L. cv. Yumai 34 seedlings following treatment with exogenous $0.5 \mathrm{mM}$ salicylic acid under drought conditions compared with the stressed plants. This enhanced tolerance is related to the increased transcription of GR and other AsA-GSH cycle-related genes, as well as the increased content and biosynthesis of AsA and GSH [46].

In contrast to the results presented above, other researchers have found that GR activity diminishes under drought conditions. For example, Iturbe-Ormaetxe et al. [47] analyzed pea (Pisum sativum L. cv. Lincoln) plants grown both under optimal water (leaf $\Psi_{w}$ values of $-0.50 \pm 0.02 \mathrm{MPa}$ ) and water deficit conditions (leaf $\Psi_{w}$ values of $-1.30 \pm 0.04$ $\mathrm{MPa}(\mathrm{S} 1)$ and $-1.93 \pm 0.05 \mathrm{MPa}(\mathrm{S} 2)$. In S1 and S2 plants, the activity of GR decreased in both regimes as compared with unstressed plants.

\section{S-Glutathionylation}

S-Glutathionylation is a redox post-translational modification of protein cysteine residues by the addition of glutathione. Protein S-glutathionylation is promoted by reactive oxygen and nitrogen species activity, but also occurs in unstressed cells. This biochemical process may serve to regulate a variety of cellular processes by modulating protein function and preventing irreversible oxidation of protein thiols [48]. Recent studies have identified S-glutathionylation as a significant mechanism of cell regulation and redox signaling in photosynthetic organisms. For example, it regulates Calvin cycle enzymes such as phosphoribulokinase, glyceraldehyde-3-phosphate dehydrogenase, ribose5-phosphate isomerase, and phosphoglycerate kinase in the green alga (Chlamydomonas reinhardtii P.A. Dang.) growing under oxidative stress conditions [49].

Desiccation is not synonymous with drought, and desiccation tolerance is defined as the ability of a living plant structure to survive drying with low relative humidity and maintain low intracellular water concentrations. Whereas drought tolerance is survival of low environmental water availability while maintaining high internal water contents. In desiccation tolerant plants, the enormous changes in the water content of tissues during wetting and drying cycles are accompanied by equally extreme fluctuations in their cellular redox state. S-glutathionylation of proteins is a biochemical factor that is likely to contribute towards protection mechanisms that confer desiccation tolerance [50]. 
Some of the best described stress-related proteins that may be subject to S-glutathionylation belong to the annexin group. The annexin protein family comprises multigene, multifunctional membrane and $\mathrm{Ca}^{2+}$-binding proteins with expected enzymatic activity involved in the signal transduction pathway. The characteristic attribute of annexins is that they can bind membrane phospholipids in a reversible, $\mathrm{Ca}^{2+}$-dependent manner [51].

In vitro studies demonstrated that Arabidopsis annexin 1 (AnnAt1) can be S-glutathionylated on two Cys residues providing important data that show these residues to be chemically reactive [52]. It has been suggested that owing to the reactivity of these Cys residues, AnnAt1 may be one of the plant cellular proteins involved in $\mathrm{H}_{2} \mathrm{O}_{2}$ perception. Furthermore, Konopka-Postupolska et al. [52] found that the Cys residues in AnnAt1 are S-glutathionylated in vivo in response to $\mathrm{ABA}$ treatment, which provides evidence that this post-translational modification of AnnAt1 is physiologically relevant during drought responses.

Drought tolerance and adaptation processes are also regulated at the molecular level. DREBs (dehydration responsive element binding) are important plant transcription factors that regulate the expression of many stress-inducible genes in the ABA-independent pathways and play an important role in increasing the abiotic stresses tolerance of plants by interacting with a cis-element present in the promoter region in abiotic stress-responsive genes. DRE (dehydration responsive element) with a 9 bp conserved DNA sequence (5'-TACCGACAT-3') was first described in the promoter of the drought-responsive gene $r d 29 A$ [53].

On perceiving a water deficit, the plant cell produces a biochemical signal, which is transduced via activation of DNA-binding proteins called CBF, which then bind to DREs on the $r d 29 A$ promoter. This precipitates intensified transcription of the gene and finally the accumulation of rd29A proteins, which probably participate in the response to drought. Furthermore, the $r d 29 A$ promoter also contains elements, which respond to ABA (ABREs). The DRE and ABRE elements probably function together to increase the rate of transcription [54].

Transgenic tomato homozygous $\mathrm{T}_{2}$ (cv. Kashi Vishesh) plants over-expressing Arabidopsis thaliana AtDREB1A/

\section{Acknowledgments}

This work was financially supported by the Department of Biochemistry, Warsaw University of Life Sciences - SGGW.

\section{Authors' contributions}

The following declarations about authors' contributions to the research have been made: compiled the literature: ML; prepared the figure: FMSA; wrote the manuscript: ML, FMSA.

\section{References}

1. Nayyar H, Gupta D. Differential sensitivity of C3 and C4 plants to water deficit stress: association with oxidative stress and antioxidants. Env Exp Bot. 2006;58(1-3):106-113. http://dx.doi.org/10.1016/j. envexpbot.2005.06.021

2. Monakhova OF, Chernyad'ev II. Protective role of kartolin-4 in wheat plants exposed to soil draught. Appl Biochem Microbiol. 2002;38(4):373-380. http://dx.doi.org/10.1023/A:1016243424428

3. Huang GT, Ma SL, Bai LP, Zhang L, Ma H, Jia P, et al. Signal
$C B F 3$ driven by stress-inducible $r d 29 A$ promoter showed significantly greater activity of GR when exposed to water deficit for 7, 14, and 21 days compared with non-transgenic plants under the same water deficit conditions. The contents of total ascorbate, total glutathione and GSH were greater in transgenic plants and increased with ROS levels. The authors demonstrated that AtDREB1A transgenic tomato lines were better adapted to water deficit, since they showed lower drought induced oxidative stress due to activation of the antioxidant response. In summary, the up-regulation of genes responsible for antioxidant defense might be a consequence of the over-expression of $A t D R E B 1 A$ in all the five transgenic tomato lines tested under drought conditions [55].

\section{Concluding remarks and future challenges}

This article gives a clear overview of the biochemical aspects of GSH and its related enzymes in a variety of plant species subjected to drought. The reviewed studies confirm that GSH plays a central role in the metabolism of plant cells during abiotic stress. Also, by acting as a key component of the Foyer-Halliwell-Asada pathway, the reduced glutathione and its related enzymes play a very important role in the protection of plants against oxidative stress induced by water deficit in tissues. GSH, its redox couple (GSH/GSSG) and related enzymes (GPXs, GSTs, GR) have been shown to be closely correlated in terms of their metabolic functions in plants during drought. Thus, the GSH system is often regarded as a useful marker in plant ecophysiological studies. However, many questions have yet to be answered, in particular regarding the regulation of S-glutathionylation and the molecular characterization of GSH-dependent enzymes in model plant organisms, wild species, and economically important crops growing under drought conditions. The present authors wish to highlight that transgenic plants over-expressing or expressing antisense constructs resulting in inhibition of specific GSH related enzymes, or mutants with impaired reactive oxygen species generation may be extremely useful in basic researches, and are likely to be valuable in subsequent analyzes of plant antioxidative mechanisms, and the role of glutathione in response to drought.

transduction during cold, salt, and drought stresses in plants. Mol Biol Rep. 2012;39(2):969-987. http://dx.doi.org/10.1007/s11033-011-0823-1

4. Mittler R. Oxidative stress, antioxidants and stress tolerance. Trends Plant Sci. 2002;7(9):405-410. http://dx.doi.org/10.1016/ S1360-1385(02)02312-9

5. Anjum SA, Wang L, Farooq M, Khan I, Xue L. Methyl jasmonate-induced alteration in lipid peroxidation, antioxidative defence system and yield in soybean under drought. J Agron Crop Sci. 2011;197(4):296301. http://dx.doi.org/10.1111/j.1439-037X.2011.00468.x

6. Sharma P, Jha AB, Dubey RS, Pessarakli M. Reactive oxygen species, oxidative damage, and antioxidative defense mechanism in plants under stressful conditions. J Bot. 2012;2012:1-26. http://dx.doi. org/10.1155/2012/217037

7. Noctor G, Foyer CH. Ascorbate and glutathione: keeping active oxygen under control. Annu Rev Plant Physiol Plant Mol Biol. 1998;49:249-279. http://dx.doi.org/10.1146/annurev.arplant.49.1.249

8. Foyer $\mathrm{CH}$, Noctor G. Redox homeostasis and antioxidant signaling: a metabolic interface between stress perception and physiological 
responses. Plant Cell. 2005;17(7):1866-1875. http://dx.doi.org/10.1105/ tpc. 105.033589

9. Gill SS, Tuteja N. Reactive oxygen species and antioxidant machinery in abiotic stress tolerance in crop plants. Plant Physiol Biochem. 2010;48(12):909-930. http://dx.doi.org/10.1016/j.plaphy.2010.08.016

10. Boguszewska D, Zagdańska B. ROS as signaling molecules and enzymes of plant response to unfavorable environmental conditions. In: Lushchak V, Semchyshyn HM, editors. Oxidative stress - molecular mechanisms and biological effects. Rijeka, Croatia: InTech; 2012. p. 341-362. http://dx.doi.org/10.5772/33589

11. Zagorchev L, Seal C, Kranner I, Odjakova M. A central role for thiols in plant tolerance to abiotic stress. Int J Mol Sci. 2013;14(4):7405-7432. http://dx.doi.org/10.3390/ijms14047405

12. Boguszewska D, Grudkowska M, Zagdańska B. Drought-responsive antioxidant enzymes in potato (Solanum tuberosum L.). Potato Res. 2010;53(4):373-382. http://dx.doi.org/10.1007/s11540-010-9178-6

13. Noctor G, Mhamdi A, Chaouch S, Han Y, Neukermans J, Marquez-Garcia B, et al. Glutathione in plants: an integrated overview. Plant Cell Env. 2012;35(2):454-484. http://dx.doi. org/10.1111/j.1365-3040.2011.02400.x

14. Zechmann B, Müller M. Subcellular compartmentation of glutathione in dicotyledonous plants. Protoplasma. 2010;246(1-4):15-24. http:// dx.doi.org/10.1007/s00709-010-0111-2

15. Wachter A, Wolf S, Steininger H, Bogs J, Rausch T. Differential targeting of GSH1 and GSH2 is achieved by multiple transcription initiation: implications for the compartmentation of glutathione biosynthesis in the Brassicaceae. Plant J. 2005;41(1):15-30. http:// dx.doi.org/10.1111/j.1365-313X.2004.02269.x

16. Sengupta D, Ramesh G, Mudalkar S, Kumar KRR, Kirti PB, Reddy AR. Molecular cloning and characterization of $\gamma$-glutamyl cysteine synthetase (Vr $\gamma \mathrm{ECS}$ ) from roots of Vigna radiata (L.) Wilczek under progressive drought stress and recovery. Plant Mol Biol Rep. 2012;30(4):894-903. http://dx.doi.org/10.1007/s11105-011-0398-y

17. Nazar R, Iqbal N, Masood A, Syeed S, Khan NA. Understanding the significance of sulfur in improving salinity tolerance in plants. Env. Exp Bot. 2011;70(2-3):80-87. http://dx.doi.org/10.1016/j. envexpbot.2010.09.011

18. Lim B, Meyer AJ, Cobbett CS. Development of glutathione-deficient embryos in Arabidopsis is influenced by the maternal level of glutathione. Plant Biol Stuttg. 2011;13(4):693-697. http://dx.doi. org/10.1111/j.1438-8677.2011.00464.x

19. El Msehli S, Lambert A, Baldacci-Cresp F, Hopkins J, Boncompagni E, Smiti SA, et al. Crucial role of (homo)glutathione in nitrogen fixation in Medicago truncatula nodules. New Phytol. 2011;192(2):496-506. http://dx.doi.org/10.1111/j.1469-8137.2011.03810.x

20. Cruz de Carvalho MH, Brunet J, Bazin J, Kranner I, d'Arcy-Lameta A, Zuily-Fodil Y, et al. Homoglutathione synthetase and glutathione synthetase in drought-stressed cowpea leaves: expression patterns and accumulation of low-molecular-weight thiols. J Plant Physiol. 2010;167(6):480-487. http://dx.doi.org/10.1016/j.jplph.2009.10.023

21. Naya L, Ladrera R, Ramos J, González EM, Arrese-Igor C, Minchin $\mathrm{FR}$, et al. The response of carbon metabolism and antioxidant defenses of alfalfa nodules to drought stress and to the subsequent secovery of plants. Plant Physiol. 2007;144(2):1104-1114. http://dx.doi. org/10.1104/pp.107.099648

22. Sgherri CLM, Navari-Izzo F. Sunflower seedlings subjected to increasing water deficit stress: oxidative stress and defence mechanisms. Physiol Plant. 1995;93(1):25-30. http://dx.doi. org/10.1034/j.1399-3054.1995.930105.x

23. Herbinger K, Tausz M, Wonisch A, Soja G, Sorger A, Grill D. Complex interactive effects of drought and ozone stress on the antioxidant defence systems of two wheat cultivars. Plant Physiol Biochem. 2002;40(6-8):691-696. http://dx.doi.org/10.1016/ S0981-9428(02)01410-9

24. Pyngrope S, Bhoomika K, Dubey RS. Reactive oxygen species, ascorbate-glutathione pool, and enzymes of their metabolism in drought-sensitive and tolerant indica rice (Oryza sativa L.) seedlings subjected to progressing levels of water deficit. Protoplasma. 2013;250(2):585-600. http://dx.doi.org/10.1007/s00709-012-0444-0
25. Anjum NA, Ahmad I, Mohmood I, Pacheco M, Duarte AC, Pereira E, et al. Modulation of glutathione and its related enzymes in plants' responses to toxic metals and metalloids - a review. Env Exp Bot. 2012;75:307-324. http://dx.doi.org/10.1016/j.envexpbot.2011.07.002

26. Tausz M, Wonisch A, Peters J, Jiménez MS, Morales D, Grill D. Short-term changes in free radical scavengers and chloroplast pigments in Pinus canariensis needles as affected by mild drought stress. J Plant Physiol. 2001;158(2):213-219. http://dx.doi. org/10.1078/0176-1617-00178

27. Anwar Hossain M, Golam Mostofa M, Fujita M. Heat-shock positively modulates oxidative protection of salt and drought-stressed mustard (Brassica campestris L.) seedlings. J Plant Sci Mol Breed. 2013;2(1):1-14. http://dx.doi.org/10.7243/2050-2389-2-2

28. Alam MM, Hasanuzzaman M, Nahar K, Fujita M. Exogenous salicylic acid ameliorates short-term drought stress in mustard (Brassica juncea L.) seedlings by up-regulating the antioxidant defense and glyoxalase system. Aust J Crop Sci. 2013;7(7):1053-1063.

29. Liu D, Pei ZF, Naeem MS, Ming DF, Liu HB, Khan F, et al. 5 -aminolevulinic acid activates antioxidative defence system and seedling growth in Brassica napus L. under water-deficit stress. J Agron Crop Sci. 2011;197(4):284-295. http://dx.doi. org/10.1111/j.1439-037X.2011.00465.x

30. Dhindsa RS. Drought stress, enzymes of glutathione metabolism, oxidation injury, and protein synthesis in Tortula ruralis. Plant Physiol. 1991;95(2):648-651. http://dx.doi.org/10.1104/pp.95.2.648

31. Pourtaghi A, Darvish F, Habibi D, Nourmohammadi G, Daneshian J. Effect of irrigation water deficit on antioxidant activity and yield of some sunflower hybrids. Aust J Crop Sci. 2011;5(2):197-204.

32. Masoumi H, Masoumi M, Darvish F, Daneshian J, Nourmohammadi G, Habibi D. Change in several antioxidant enzymes activity and seed yield by water deficit stress in soybean (Glycine max L.) cultivars. Bot Hort Agrobot Cluj. 2010;38(3):86-94.

33. Sayfzadeh S, Rashidi M. Response of antioxidant enzymes activities of sugar beet to drought stress. J Agric Biol Sci. 2011;6(4):27-33.

34. Gaber A, Yoshimura K, Yamamoto T, Yabuta Y, Takeda T, Miyasaka $\mathrm{H}$, et al. Glutathione peroxidase-like protein of Synechocystis PCC 6803 confers tolerance to oxidative and environmental stresses in transgenic Arabidopsis. Physiol Plant. 2006;128(2):251-262. http:// dx.doi.org/10.1111/j.1399-3054.2006.00730.x

35. Miao Y, Lv D, Wang P, Wang XC, Chen J, Miao C, et al. An Arabidopsis glutathione peroxidase functions as both a redox transducer and a scavenger in abscisic acid and drought stress responses. Plant Cell. 2006;18(10):2749-2766. http://dx.doi.org/10.1105/tpc.106.044230

36. Kojić D, Pajević S, Jovanović-Galović A, Purać J, Pamer E, Škondrić $S$, et al. Efficacy of natural aluminosilicates in moderating drought effects on the morphological and physiological parameters of maize plants (Zea mays L.). J Soil Sci Plant Nutr. 2012;12(1):113-123. http:// dx.doi.org/10.4067/S0718-95162012000100010

37. Gallé A, Csiszár J, Secenji M, Guóth A, Cseuz L, Tari I, et al. Glutathione transferase activity and expression patterns during grain filling in flag leaves of wheat genotypes differing in drought tolerance: response to water deficit. J Plant Physiol. 2009;166(17):1878-1891. http://dx.doi. org/10.1016/j.jplph.2009.05.016

38. Chen JH, Jiang HW, Hsieh EJ, Chen HY, Chien CT, Hsieh HL, et al. Drought and salt stress tolerance of an Arabidopsis glutathione Stransferase U17 knockout mutant are attributed to the combined effect of glutathione and abscisic acid. Plant Physiol. 2012;158(1):340-351. http://dx.doi.org/10.1104/pp.111.181875

39. George S, Venkataraman G, Parida A. A chloroplast-localized and auxin-induced glutathione S-transferase from phreatophyte Prosopis juliflora confer drought tolerance on tobacco. J Plant Physiol. 2010;167(4):311-318. http://dx.doi.org/10.1016/j.jplph.2009.09.004

40. Ji W, Zhu Y, Li Y, Yang L, Zhao X, Cai H, et al. Over-expression of a glutathione S-transferase gene, GsGST, from wild soybean (Glycine soja) enhances drought and salt tolerance in transgenic tobacco. Biotechnol Lett. 2010;32(8):1173-1179. http://dx.doi.org/10.1007/ s10529-010-0269-X

41. Ratnayaka HH, Molin WT, Sterling TM. Physiological and antioxidant responses of cotton and spurred anoda under interference and 
mild drought. J Exp Bot. 2003;54(391):2293-2305. http://dx.doi. org/10.1093/jxb/erg251

42. Lei Y, Yin C, Li C. Differences in some morphological, physiological, and biochemical responses to drought stress in two contrasting populations of Populus przewalskii. Physiol Plant. 2006;127(2):182-191. http://dx.doi.org/10.1111/j.1399-3054.2006.00638.x

43. Pinheiro HA, DaMatta FM, Chaves ARM, Fontes EPB, Loureiro ME. Drought tolerance in relation to protection against oxidative stress in clones of Coffea canephora subjected to long-term drought. Plant Sci. 2004;167(6):1307-1314. http://dx.doi.org/10.1016/j. plantsci.2004.06.027

44. Singh S, Gupta AK, Kaur N. Differential responses of antioxidative defence system to long-term field drought in wheat (Triticum aestivum L.) genotypes differing in drought tolerance. J Agron Crop Sci. 2012;198(3):185-195. http://dx.doi. org/10.1111/j.1439-037X.2011.00497.x

45. Ünyayar S, Çekiç FÖ. Changes in antioxidative enzymes of young and mature leaves of tomato seedlings under drought stress. Turk J Biol. 2006;29(4):211-216.

46. Kang GZ, Li GZ, Liu GQ, Xu W, Peng XQ, Wang CY, et al. Exogenous salicylic acid enhances wheat drought tolerance by influence on the expression of genes related to ascorbate-glutathione cycle. Biol Plant. 2013;57(4):718-724. http://dx.doi.org/10.1007/s10535-013-0335-z

47. Iturbe-Ormaetxe I, Escuredo PR, Arrese-Igor C, Becana M. Oxidative damage in pea plants xxposed to water deficit or paraquat. Plant Physiol. 1998;116(1):173-181. http://dx.doi.org/10.1104/pp.116.1.173

48. Dalle-Donne I, Rossi R, Colombo G, Giustarini D, Milzani A. Protein S-glutathionylation: a regulatory device from bacteria to humans. Trends Biochem Sci. 2009;34(2):85-96. http://dx.doi.org/10.1016/j. tibs.2008.11.002

49. Zaffagnini M, Bedhomme M, Groni H, Marchand CH, Puppo C, Gontero B, et al. Glutathionylation in the photosynthetic model organism Chlamydomonas reinhardtii: a proteomic survey. Mol Cell Proteomics. 2012;11(2):M111.014142. http://dx.doi.org/10.1074/ mcp.M111.014142

50. Colville L, Kranner I. Desiccation tolerant plants as model systems to study redox regulation of protein thiols. Plant Growth Regul. 2010;62(3):241-255. http://dx.doi.org/10.1007/s10725-010-9482-9

51. Talukdar T, Gorecka KM, de Carvalho-Niebel F, Downie JA, Cullimore J, Pikula S. Annexins - calcium- and membrane-binding proteins in the plant kingdom: potential role in nodulation and mycorrhization in Medicago truncatula. Acta Biochim Pol. 2009;56(2):199-210.

52. Konopka-Postupolska D, Clark G, Goch G, Debski J, Floras K, Cantero A, et al. The role of annexin 1 in drought stress in Arabidopsis. Plant Physiol. 2009;150(3):1394-1410. http://dx.doi.org/10.1104/ pp.109.135228

53. Lata C, Prasad M. Role of DREBs in regulation of abiotic stress responses in plants. J Exp Bot. 2011;62(14):4731-4748. http://dx.doi. org/10.1093/jxb/err210

54. Hamill JD. Gene expression modified by external factors. In: Turnbull CGN, Atwell BJ, Kriedemann PE, editors. Plants in action. Adaptation in nature, performance in cultivation. Melbourne, Australia: Macmillan Education Australia Pty Ltd; 1999. p. 10.3.4.

55. Rai GK, Rai NP, Rathaur S, Kumar S, Singh M. Expression of rd29A::AtDREB1A/CBF3 in tomato alleviates drought-induced oxidative stress by regulating key enzymatic and non-enzymatic antioxidants. Plant Physiol Biochem. 2013;69:90-100. http://dx.doi. org/10.1016/j.plaphy.2013.05.002

56. Pandey HC, Baig MJ, Chandra A, Bhatt RK. Drought stress induced changes in lipid peroxidation and antioxidant system in genus Avena. J Env. Biol. 2010;31(4):435-440.

57. Chowdhury SR, Choudhuri MA. Hydrogen peroxide metabolism as an index of water stress tolerance in jute. Physiol Plant. 1985;65(4):476480. http://dx.doi.org/10.1111/j.1399-3054.1985.tb08676.x

58. Wang S, Liang D, Li C, Hao Y, Ma F, Shu H. Influence of drought stress on the cellular ultrastructure and antioxidant system in leaves of drought-tolerant and drought-sensitive apple rootstocks. Plant Physiol Biochem. 2012;51:81-89. http://dx.doi.org/10.1016/j. plaphy.2011.10.014
59. Bai LP, Sui FG, Ge TD, Sun ZH, Lu YY, Zhou GS. Effect of soil drought stress on leaf water status, membrane permeability and enzymatic antioxidant system of maize. Pedosphere. 2006;16(3):326-332. http:// dx.doi.org/10.1016/S1002-0160(06)60059-3

60. Ali Q, Ashraf M. Induction of drought tolerance in maize (Zea mays L.) due to exogenous application of trehalose: growth, photosynthesis, water relations and oxidative defence mechanism. J Agron Crop Sci. 2011;197(4):258-271. http://dx.doi. org/10.1111/j.1439-037X.2010.00463.x

61. Anjum SA, Wang LC, Farooq M, Hussain M, Xue LL, Zou CM. Brassinolide application improves the drought tolerance in maize through modulation of enzymatic antioxidants and leaf gas exchange. J Agron Crop Sci. 2011;197(3):177-185. http://dx.doi. org/10.1111/j.1439-037X.2010.00459.x

62. Anjum SA, Wang L, Farooq M, Xue L, Ali S. Fulvic acid application improves the maize performance under well-watered and drought conditions. J Agron Crop Sci. 2011;197(6):409-417. http://dx.doi. org/10.1111/j.1439-037X.2011.00483.x

63. Yildiz-Aktas L, Dagnon S, Gurel A, Gesheva E, Edreva A. Drought tolerance in cotton: involvement of non-enzymatic ROS-scavenging compounds. J Agron Crop Sci. 2009;195(4):247-253. http://dx.doi. org/10.1111/j.1439-037X.2009.00366.x

64. Sairam RK, Shukla DS, Saxena DC. Stress induced injury and antioxidant enzymes in relation to drought tolerance in wheat genotypes. Biol Plant. 1997;40(3):357-364. http://dx.doi.org/10.1023/A:1001009812864

65. Marcińska I, Czyczyło-Mysza I, Skrzypek E, Grzesiak MT, Janowiak F, Filek M, et al. Alleviation of osmotic stress effects by exogenous application of salicylic or abscisic acid on wheat seedlings. Int J Mol Sci. 2013;14(7):13171-13193. http://dx.doi.org/10.3390/ijms140713171

66. Zlatev ZS, Lidon FC, Ramalho JC, Yordanov IT. Comparison of resistance to drought of three bean cultivars. Biol Plant. 2006;50(3):389394. http://dx.doi.org/10.1007/s10535-006-0054-9

67. Fazeli F, Ghorbanli M, Niknam V. Effect of drought on biomass, protein content, lipid peroxidation and antioxidant enzymes in two sesame cultivars. Biol Plant. 2007;51(1):98-103. http://dx.doi.org/10.1007/ s10535-007-0020-1

68. Mohammadi A, Habibi D, Rohami M, Mafakheri S. Effect of drought stress on antioxidant enzymes activity of some chickpea cultivars. Am-Eurasian J Agric Env Sci. 2011;11(6):782-785.

69. Huang C, Zhao S, Wang L, Anjum SA, Chen M, Zhou H, et al. Alteration in chlorophyll fluorescence, lipid peroxidation and antioxidant enzymes activities in hybrid ramie (Boehmeria nivea L.) under drought stress. Aust J Crop Sci. 2013;7(5):594.

70. Štajner D, Orlović S, Popović BM, Kebert M, Galić Z. Screening of drought oxidative stress tolerance in Serbian melliferous plant species. Afr J Biotechnol. 2011;10(9):1609-1614.

71. Habibi G, Hajiboland R. Alleviation of drought stress by silicon supplementation in pistachio (Pistacia vera L.) plants. Folia Hort. 2013;25(1):21-29. http://dx.doi.org/10.2478/fhort-2013-0003

72. El-Enany AE, AL-Anazi AD, Dief N, Al-Taisan WA. Role of antioxidant enzymes in amelioration of water deficit and waterlogging stresses on Vigna sinensis plants. J Biol Earth Sci. 2013;3(1):B144-B153.

73. Farissi M, Bouizgaren A, Faghire M, Bargaz A, Ghoulam C. Agrophysiological and biochemical properties associated with adaptation of Medicago sativa populations to water deficit. Turk J Bot. 2013;37:1166-1175. http://dx.doi.org/10.3906/bot-1211-16

74. Yobi A, Wone BWM, Xu W, Alexander DC, Guo L, Ryals JA, et al. Metabolomic profiling in Selaginella lepidophylla at various hydration states provides new insights into the mechanistic basis of desiccation tolerance. Mol Plant. 2013;6(2):369-385. http://dx.doi.org/10.1093/ $\mathrm{mp} / \mathrm{sss} 155$

75. Bednarski W, Hendry G, Atherton N, Lee J. Radical formation and accumulation in vivo, in desiccation tolerant and intolerant mosses. Free Radic Res Commun. 1991;15(3):133-141.

76. Shi H, Wang Y, Cheng Z, Ye T, Chan Z. Analysis of natural variation in bermudagrass (Cynodon dactylon) reveals physiological responses underlying drought tolerance. PLoS ONE. 2012;7(12):e53422. http:// dx.doi.org/10.1371/journal.pone.0053422 
77. Zhang Y, Zhang Q, Sammul M. Physiological integration ameliorates negative effects of drought stress in the clonal herb Fragaria orientalis. PLoS ONE. 2012;7(9):e44221. http://dx.doi.org/10.1371/journal. pone. 0044221

78. Gechev TS, Van Breusegem F, Stone JM, Denev I, Laloi C. Reactive oxygen species as signals that modulate plant stress responses and programmed cell death. Bioessays. 2006;28(11):1091-1101. http:// dx.doi.org/10.1002/bies.20493

79. Masoumi H, Darvish F, Daneshian J, Normohammadi G, Habibi D. Effects of water deficit stress on seed yield and antioxidants content in soybean (Glycine max L.) cultivars. Afr J Agr Res. 2011;6(5):1209-1218. http://dx.doi.org/10.5897/AJAR10.821 